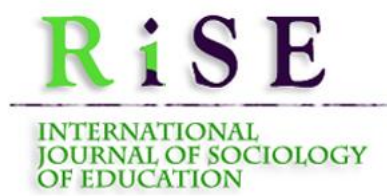

Hipatia Press

www.hipatiapress.com

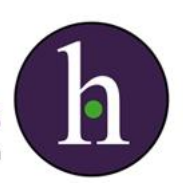

Instructions for authors, subscriptions and further details:

http://rise.hipatiapress.com

\title{
Bullying. Description of the Roles of Victim, Bully, Peer Group, School, Family and Society
}

Miguel Urra Canales ${ }^{1}$

Catalina Acosta Oidor ${ }^{1}$

Verónica Salazar Baena ${ }^{1}$

Edwin Jaime Ruiz ${ }^{1}$

1) Universidad Santo Tomás, Colombia

Date of publication: October $25^{\text {th }}, 2018$

Edition period: October 2018-February 2019

To cite this article: Urra Canales, M., Acosta Oidor, C., Salazar Baena, V., Jaime Ruiz, E. (2018). Bullying. Description of the Roles of Victim, Bully, Peer Group, School, Family and Society, International Journal of Sociology of Education, 7(3), 278-299. doi: 10.17583/rise.2018.3547

To link this article: http://dx.doi.org/10.17583/rise.2018.3547

PLEASE SCROLL DOWN FOR ARTICLE

The terms and conditions of use are related to the Open Journal System and to Creative Commons Attribution License (CC-BY) 


\section{Bullying. Description of the Roles of Victim, Bully, Peer Group, School, Family and Society}

Miguel Urra Canales

University of Santo Tomás

Verónica Salazar Baena

University of Santo Tomás
Catalina Acosta Oidor

University of Santo Tomás

Edwin Jaime Ruiz

University of Santo Tomás

(Received: 12 June 2018; Accepted: 20 September 2018; Published: 25 October 2018)

\section{Abstract}

This research defines, through an extensive literature review, the roles played by the victim, bully, peer group, school, family and society in the dynamics of bullying. Finally, we conclude that the complexity and diversity of the actors should lead us to rethink the traditional definitions of school bullying, to stake out the focus of research projects and to reconstruct prevention and action policies..

Keywords: bullying, school bullying, roles 


\section{Acoso Escolar. Descripción de los Roles de Víctima, Acosador, Grupo de Iguales, Escuela, Familia y Sociedad.}

Miguel Urra Canales

University of Santo Tomás

Verónica Salazar Baena

University of Santo Tomás
Catalina Acosta Oidor

University of Santo Tomás

Edwin Jaime Ruiz

University of Santo Tomás

(Recibido: 12 Junio 2018; Aceptado: 20 Septiembre 2018; Publicado: 25 Octubre 2018)

\section{Resumen}

Esta investigación define, a través de una amplia revisión bibliográfica, los roles desempeñados por la víctima, el acosador, el grupo de pares, la escuela, la familia y la sociedad en la dinámica del acoso escolar. Finalmente, concluimos que la complejidad y diversidad de los actores debería llevarnos a repensar las definiciones tradicionales de acoso escolar, a reenfocar los proyectos de investigación y a reconstruir las políticas de prevención y acción.

Palabras clave: acoso, acoso escolar, roles

2018 Hipatia Press

ISSN: 2014-3575

DOI: $10.17583 /$ rise.2018.3631

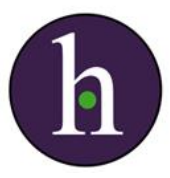


he Universal Declaration of the Rights of Boys and Girls gathers the right of all children to enjoy an educational system and to develop as people in healthy and safe conditions. Bullying at school would at the same time violate these two fundamental rights.

Bullying, understood as those "physical or psychological actions, with the intention of doing harm and repeated over time, which are directed towards a defenseless student" (Urra, 2017) is a structural problem in all the educational systems of the world. Thousands of children suffer every day mistreatment, insults, threats, coercion, beatings and humiliation. Many times, research focuses on a school, a region or a country but, since it is a problem of large dimensions and common to all school systems, it is necessary to approach it from a macro and sociological perspective. However, this global perspective should not separate us from each specific case, but rather, should help us to understand it better, so before raising the perspective to a general level, it is worth remembering what a child can feel at the particular (Tettner, 2005):

If my lunchbox spoke,

It would tell you how sad it gets every time we have to eat alone at school.

If my ears spoke,

They would tell you what torment they feel when someone makes fun of me.

If my shoes talked,

They would tell you how fast they run when we want to get to a safe place.

If my glasses spoke,

They would tell you about all the things I see and do not say anything about.

If my watch spoke,

It would tell you that when I'm late for classes it's because I'm scared.

If my notebooks spoke,

They would tell you that my best thoughts are not there.

If my school report card spoke,

It would tell you that with so much pain I can not have better grades.

If your heart listens when mine wants to talk to you ... 
These lines should reach the heart of the researcher who is reading them and invite them to try to understand in depth this phenomenon, which, as has already been pointed out, is of growing importance in school environments. Consulting SCOPUS, between 1990 and June 1, 2018, exactly 3,084 articles on bullying have been published, with a strong rebound since 2008.

Precisely, in 2018, it has been detected that $8 \%$ of the articles that address bullying are doing it from a role perspective. For example, from the social status of the aggressors (Longobardi, et. al. 2018), the role of the school (Hall \& Chapman, 2018), the role of teachers (Nappa, et. al 2018), the role of the family (Zhu, et al., 2018). One of the most interesting (Goldbach, et. al., 2018), even investigates the multiplicity of roles (for example, being attacked and aggressor at the same time).

This research starts from the fact that bullying, as a social fact, transcends the individual and does not occur only between two people, a harasser and a harassed person. On the contrary, it takes place in a role play in which we could identify, at least, the victim, the harasser, the peer group, the school, the family and society.

With this approach, the objective of this article is to describe each of these roles and show some conclusions that may help to better understand the phenomenon of bullying.

\section{Results and Findings}

Before analyzing the different roles one by one, it is convenient to see what specific weight each one has within the bullying. An approximation could be the following: 
Table 1

Role distribution

\begin{tabular}{llll}
\hline Role & Male & Female & Total \\
\hline Neutral & 14.7 & 31.2 & 22.5 \\
Witnesses & 26.4 & 22.4 & 24.5 \\
Aggressors & 4.4. & 1.7 & 3.1 \\
Víctims & 32.0 & 33.8 & 32.9 \\
Aggressors-Victims & 22.6 & 10.9 & 17.0 \\
TOTAL (N=5217) & 100 & 100 & 100 \\
\hline
\end{tabular}

Source: Smith, Singer, Hoel, \& Cooper, (2003)

\section{Victims}

A survey of teachers and students in the United Kingdom indicates that both, when defining bullying, refer to the victim as a person who is physically and psychologically harmed, and who suffers fear because he is continually intimidated (Naylor, 2006). It is difficult to establish a single profile of the victims, but we can delve into certain characteristics that people who suffer bullying usually have.

\section{Age}

Surveys show that the most prevalent age of bullying is 10 to 13 years, that is, preadolescence. These same surveys indicate that at 18 years of age, cases of bullying are almost nil (Eslea \& Rees, 2001).

However, another series of studies, which use qualitative techniques in addition to the direct survey of students, do not find significant differences in the incidence of bullying with respect to age. That is, there would be cases at all ages (Johnson, 2002).

The investigations that try to reconcile the two visions previously exposed, maintain the critical age in the 10-13 years, but they add an important nuance: the self-report of bullying (those students that when answering the surveys are considered harassed) diminishes with the age; while the reports of teachers or classmates do not behave in the same way, remaining practically the same throughout all the school stages (Salmivalli, 2002). 


\section{Gender}

Both boys and girls are victims of bullying, and even with more similar forms of aggression. However, in this section we will refer to another fact: gender conflicts in victims of bullying.

Various studies indicate that children who deviate from the "codes of masculinity" (they cry, show weakness ...) are more prone to suffer aggressions. Likewise, it is observed that homosexual students are attacked more frequently. There is even the sad case that homophobic bullying is more tolerated in general terms (Phoenix, Frosh \& Pattman, 2003).

\section{Sociological profile}

The different researches carried out indicate that bullying appears in all social strata.

For example, in South Africa (a country with a marked inequality of access to education), a study revealed that cases of bullying appeared equally in schools with predominantly white students, than in schools with mostly black students; and bullying was found in schools with upper class students as well as in schools with students from less favored classes (Eisenberg, Neumark-Sztainer \& Perry, 2003). In this sense, other researchs do show that the fact of belonging to an ethnic minority places the students most likely to be attacked, but also more likely to become aggressors (Fleschler, Tortolero \& Markham, 2006).

Also, in Finland a large survey on school bullying was conducted, and the results indicated that cases appeared in both cities and smaller towns. This same survey, however, did conclude that living with a single parent, either the father or the mother, slightly increased the chances of becoming a victim, but also the possibilities of becoming an aggressor (Nordhagen, Nielsen, Stigum \& Köhler, 2005).

\section{Psychological profile}

A survey of teachers and students can show us in a very basic way the psychological profile of victims of bullying: people who seem frightened, people who seem vulnerable and sad people (Fox \& Boulton, 2005).

Deepening a little more, the research revealed that students who suffer bullying value their stay at school more negatively. In addition, it has also 
been shown that students who are victims of bullying often get worse grades than the rest of their classmates (Eisenberg, Neumark-Sztainer \& Perry, 2003).

Already on a more concrete level, it is demonstrated that victims of bullying suffer more psychological problems than their peers, as can be seen in the following table:

Table 2

Proportion of psychological problems between victims and the common students.

\begin{tabular}{lllll}
\hline Problem & Víctims & No víctims & $\mathrm{P}$ & $\mathrm{R}^{2}$ \\
\hline Some recurrent psychosomatic problem & $31,5 \%$ & $19,7 \%$ & $<0,001$ & 1,6 \\
Carelessness in appearance & $13,6 \%$ & $4,6 \%$ & $<0,001$ & 3,0 \\
Anxiety & $12,7 \%$ & $4,4 \%$ & $<0,001$ & 2,9 \\
Depression & $6,8 \%$ & $1,9 \%$ & $<0,001$ & 3,6 \\
Loneliness & $14,5 \%$ & $4,8 \%$ & $<0,001$ & 3,0 \\
Dependence & $14,2 \%$ & $5,3 \%$ & $<0,001$ & 2,8 \\
Passivity & $8,9 \%$ & $4 \%$ & $<0,001$ & 2,2 \\
Restless & $18,6 \%$ & $7,4 \%$ & $<0,001$ & 2,5 \\
Need for special education & $15,1 \%$ & $5,8 \%$ & $<0,001$ & 2,6 \\
\hline
\end{tabular}

Source: Nordhagen, Nielsen, Stigum \& Köhler (2005).

\section{Physical profile}

The different theories about "first impressions" give great importance to the physical aspect, since it is our "facade", what stands out at sight, what is first seen. In other words, we could say that the physical aspect is what first differentiates us from the rest of the people around us and, unfortunately, those students who are "different" are the target of a multitude of harassing behaviors. For example, students who are overweight, have a disability or use orthodontics.

In this sense, it has been found, for example, that research shows that boys and girls who wear glasses or suffer from a visual disorder have higher rates of bullying (Honwood, Waylen \& Herrick, 2005).

\section{Response to abuses}

According to several researches carried out with large samples and diverse 
quantitative and qualitative methodologies (Lawrence \& Adams, 2006; Salmivalli, 2002; Mahady, Craig \& Pepler, 2000), we could distinguish two large groups of victims. The first, would be formed by victims with low aggressiveness: before the harassment show anxiety and insecurity. They neither provoke the harasser nor try to resist the aggressions, they usually cry and "give up". The second, the victims would form with high aggressiveness: before the harassment, they show opposition and sometimes they try to repel the aggressions.

It is known that fear, guilt or shame leads victims to hide their situation and try to adapt to it. For this reason, it would be important to study the "practical response" made by the victims. For example, if they report the case themselves to the teachers, or confess their situation to their family and friends; and if they do not, it should be ascertained what factors would facilitate the reporting of the facts.

\section{Causal attribution.}

An important variable when analyzing bullying is the causal attribution made by the victims; In other words, why do they think they are being bullied.

Table 3

Causal attribution of those who are bullied.

("If you have been intimidated on occasion, why do you think they did it?")

\begin{tabular}{ll}
\hline Because I am the weakest & $36,5 \%$ \\
For bothering me & $34,8 \%$ \\
Because I'm different from them & $30,4 \%$ \\
I do not know & $30,4 \%$ \\
For making a joke & $9,6 \%$ \\
Because I provoked them & $6,1 \%$ \\
Because I deserve it & $1,8 \%$ \\
\hline
\end{tabular}

Source: Avilés (2006)

As you can see, the answers are diverse, but three major groups stand out: feeling weak or feeling different, those who think that bullying is occurring to annoy them or those who do not know how to attribute a cause. This last 
group is especially dramatic, since this "not knowing" generates greater stress and frustration in the victim, which prevents him from building patterns of defensive behavior.

\section{Future perspectives}

Each case is different, and it is not possible to generalize about how some victims and others will evolve over time. However, research points to certain trends.

Longitudinal studies show that victims of severe bullying in school suffer sequelae throughout their lives: in addition to low self-esteem, they have difficulties making friends and being successful in their professional and social lives. As a significant fact, one of these investigations showed that $46 \%$ of the people who suffered this severe harassment, has ever considered suicide (Lynch, 2004)

Another series of longitudinal studies, carried out from a gender perspective, showed that women who suffered bullying were more likely to be prone to depression when they were adults. In the same way, males who were victims of bullying, had in their adult stage more difficulties to establish romantic relationships (Lawrence \& Adams, 2006).

To conclude this section, to say that a certain relationship has also been found between being a victim of bullying and then being a victim of workplace bullying in adult professional life (Smith, Singer, Hoel \& Cooper, 2003)

\section{The Bully}

\section{Age}

The aggressor may be elder than the victim, or have the same age. In the literature review, no studies have been found that show school bullying from younger to elder.

\section{Gender}

In the case of male aggressors, their behaviors are often associated with "masculinity codes". Because of this, traditional studies show that boys tend to practice harassment in a more direct, more physical way, while girls harass in a more subtle, more psychological way. For example, experts refer 
to an increase in cyberbullying among girls because new technologies are perfect for spreading rumors, recordings and denigrating messages (Long, 2006).

However, the most recent research seems to indicate that more and more girls are exercising more direct forms of violence and aggression.

\section{Sociological profile}

Some studies have come to show that children, who bully their peers, largely come from a family where you can also find aggressors. In this sense, in studies based on life stories, three generations of bullies have even been found (Lawrence \&Adams, 2006).

Regarding the social status of the aggressors, suffice it to say that we find cases of bullying in both the most elite schools and the humblest schools.

\section{Psychological profile}

At the time of defining psychologically the students who harass their peers, we would find two profiles.

On the one hand, some studies have found a correlation between feeling low self-esteem or depressive symptoms, and ending up becoming an aggressor (Karstadt \& Woods, 1999). In a similar vein, other studies have concluded that boys and girls who have family problems also end up as aggressors (Roland, 2002).

On the other hand, there are studies that emphasize that the aggressor enjoys good self-esteem, and even exercises the leadership of a group (Sutton, Smith \& Swettenham 1999; Patterson, 2005).

\section{Causal attribution.}

In the first place, it is important to observe the causal self-report offered by the bullies, that is, why they believe they carry out acts of harassment in school. 
Table 4

Causal attribution of the bullys.

("If you have participated in situations of intimidation towards your classmates, why did you do it?)

\begin{tabular}{ll}
\hline Because they provoked me & $64 \%$ \\
For making a joke & $33,6 \%$ \\
For annoying & $15,2 \%$ \\
Because I'm bullied too & $12,8 \%$ \\
Because they were weaker & $4,8 \%$ \\
Because they are different & $4 \%$ \\
\hline
\end{tabular}

Note: In the case of aggressors who have been previously victims of harassment, the majority response, with $35.3 \%$, is " Because I’m bullied too ".

Source: Avilés, (2006)

In addition to these self-reported data by the stalkers, the experts describe three aspects for which the stalker performs his bullying actions (Lawrence \& Adams, 2006): a) Receive material rewards: the victims end up giving their money, your lunch, your toys ... etc. b) receives immaterial rewards: he feels power and a superior position and c) feels some impunity, since he usually chooses those comrades who will not confess the abuse before the professors.

Other researchs imply that the feeling of power is the main reinforcer of the harasser, that is why they choose victims that they consider weak and submissive, "dominable" (Patterson, 2005).

\section{Bullying actions}

A detailed list of harassment actions could be the following: to call him by nicknames, not to speak to him, to laugh at him when he makes a mistake, to insult him, to accuse him of things he has not said or done, to tell lies about him, mess with him for his way of being, make fun of his physical appearance, not let him play with the group, make gestures of mockery or contempt towards him, scream or yell at him, criticize everything he does, imitate him to mock, hate him no reason, change the meaning of what he says, hit him with punching / punching / kicking, not letting him talk, hiding 
things, making a fool of him, having a mania, messing with him to make him cry, telling others not to be with him or do not talk to him, mess with him because of his way of speaking, mess with him for being different or stealing his things (Oñate \& Piñuel, 2006).

In addition to these behaviors, new technologies have opened a new field for harassment, which is known as "cyberbullying" (Stover, 2006). This electronic harassment occurs through messages or calls from mobile phones, through email, through chats or instant messaging services, or through the dissemination of videos or photographs on web pages. Three surveys, conducted in 2006 in England and Sweden, spoke respectively of 6.6\%, 9\% and $5 \%$ of students victims of some type of harassment through electronic means. In addition, these investigations show that both victims and cyberaggressors are usually also habitual victims and aggressors (Smith, 2006). Another survey, conducted in 2003 in the United States, accounted for up to $42 \%$ of minors victims of cyberbullying.

These studies also highlight the specific dangers that this new type of bullying poses to traditional forms: a) It can occur both inside and outside the school, b) the victim cannot defend himself, and cannot flee or hide, c) harassers can hide behind the anonymity and d) the audience of cyberbullying is very broad (this takes on special relevance when spreading rumors, or showing compromising photographs or videos).

This form of aggression must be taken into account when legislating about bullying or when planning preventive actions. For example, in the United States, in 2007, when Facebook and Twitter were barely taking their first steps, twelve states had already initiated measures to criminalize cyberbullying.

\section{The Peer Group.}

In the previous sections we have studied the victim and the aggressor. However, school mistreatment always occurs in a context, within a group of equals that either may take sides with the aggressor or may defend the victim.

To refer to this group, the different articles use the English term "bystander", which we could translate as "witness" or, in a more colloquial way, as "voyeur". The role played by these "witnesses" is fundamental, since 
if they participate in the harassment they lead to the exclusion of the victim, but if they defend the victim it is very likely that the aggressions will disappear.

In view of the great importance of the group of comrades, there have been many studies on their behavior, being defined the three positions that can be taken: the group that reinforces the harassment, the group that defends the harassed and the group that ignores the situation.

As for the first, the group that reinforces the harassment, a series of characteristics have been identified that are usually related to the students who take sides with the harasser (Lodge \& Frydenberg, 2005): They maintain a friendship with the aggressor, have low self-esteem, give their friends low emotional support, establish friendships with a high degree of stress and dissatisfaction, have low self-control, their strategies to deal with embarrassing situations are ineffective or express less altruistic feelings and actions. As for the reasons to support the aggressor, we would find the following (Rigby \& Johnson, 2005): It is the safest option (not to look for problems and follow the game to the strongest), admiration towards the aggressor (assaulting a partner is considered fun) or hostility toward the victim ("he deserves it").

Regarding the second group, which defends the victim, a series of characteristics have been identified that are usually related to the students who take sides with the victim (Rigby \& Johnson, 2005): They maintain a friendship with the victim, their strategies to deal with difficult situations are effective, have good self-esteem, express altruistic feelings or give strong emotional support in their friendship relationships. A study in Australia asked four hundred students about whether they would defend a victim of bullying in cases of verbal or physical harassment, and the results were as follows: 
Table 5

Acting in a case of verbal harassment $(N=400)$

\begin{tabular}{llll}
\hline & $\begin{array}{l}\text { Probably would act } \\
\text { to defend the victim }\end{array}$ & $\begin{array}{l}\text { Not sure what } \\
\text { would do }\end{array}$ & $\begin{array}{l}\text { Probably would not } \\
\text { act to defend the } \\
\text { victim }\end{array}$ \\
\hline Primary boys & $54 \%$ & $26 \%$ & $21 \%$ \\
Primary girls & $66 \%$ & $26 \%$ & $8 \%$ \\
High school boys & $30 \%$ & $36 \%$ & $34 \%$ \\
High school girls & $39 \%$ & $40 \%$ & $21 \%$ \\
\hline
\end{tabular}

Source: Rigby \& Johnson (2006)

Table 6

Acting in a case of physical harassment $(N=400)$

\begin{tabular}{llll}
\hline & $\begin{array}{l}\text { Probably would act } \\
\text { to defend the victim }\end{array}$ & $\begin{array}{l}\text { Not sure what } \\
\text { would do }\end{array}$ & $\begin{array}{l}\text { Probably would not } \\
\text { act to defend the } \\
\text { victim }\end{array}$ \\
\hline Primary boys & $41 \%$ & $37 \%$ & $22 \%$ \\
Primary girls & $53 \%$ & $32 \%$ & $15 \%$ \\
High school boys & $31 \%$ & $31 \%$ & $28 \%$ \\
High school girls & $33 \%$ & $42 \%$ & $25 \%$ \\
\hline
\end{tabular}

Source: Rigby \& Johnson (2006)

As for the reasons to help the victim, we would find the following (Rigby \& Johnson, 2006): Negative moral judgment on the aggression (it is not good to abuse others), identification with the victim (well for having suffered assaults previously, either in solidarity with the victim, or because "I would not like to see myself in the same situation"), reciprocity (if I help, win a new friend) or self-fulfillment (feeling happy for helping others, feeling good person).

In Spain, the Report on School Violence, prepared in 1999 by the Ombudsman, asked the students: "What do you do when you continuously get in with a partner?" And the answers were the following: 
Table 7

Attitudes of Spanish students in a case of bullying.

\begin{tabular}{ll} 
They help the victim, if they have friendship with her & $44 \%$ \\
They help the victim, even if they have no friendship with her. & $32,6 \%$ \\
They warn an adult & $10 \%$ \\
They do not do anything & $18,5 \%$ \\
They do not do anything, but they think something should be done & $14 \%$ \\
They also attack the victim & $1,5 \%$ \\
\hline
\end{tabular}

Source: Informe Sobre Violencia Escolar. (DDP, 1999)

Finally, a series of characteristics that tend to be related to students who ignore harassment situations have been identified (Lodge \& Frydenberg, 2005): They have a high level of self-control, they do not usually know the people attacked and when they observe situations of abuse, then refer feelings of sadness, disgust, anger, guilt, confusion and "not knowing what to do".

As for the reasons for ignoring the situation, we would find the following (Rigby \& Johnson, 2005): They do not consider it their problem, fear of the consequences (both to be attacked directly, and to be rejected by the group ), holding the victim responsible ("he must learn to defend himself" or "something he has done"), they consider that his intervention would only make things worse ("if we do not pay attention to him, the aggressor will stop") and there are even those who say that they enjoy the show, enjoy being spectators.

\section{Causal attribution.}

In previous points, the causal attribution of victims and aggressors has been addressed, but it is also important to know the point of view of the peer group. 
Table 8

Causal attribution of those who contemplate abuse.

("Why do you think some children intimidate others?)

\begin{tabular}{ll}
\hline For annoying & $61,7 \%$ \\
Because they are stronger & $30,6 \%$ \\
For making a joke & $25,1 \%$ \\
Because they mess with them, provoke them & $21,3 \%$ \\
\hline
\end{tabular}

Source: Avilés, (2006)

As can be seen, a quarter of students see bullying as a joke or a game. However, 92\% identify some causes related to the spirit of causing harm (disturbing and using force)

\section{The School}

When we talk about school, we do it as an institution. That is to say that, for the purposes of this study, when we speak of "school" we do so in reference to both primary schools, as well as secondary schools.

\section{Institutional role}

The school is the place where bullying behaviors manifest themselves. On the one hand, schools and institutes are the physical scenario where bullying occurs and, on the other hand, their internal organization plays an active role in the dynamics of abuse. In this way, we could talk about the school as a scenario of abuse and the school as an active agent of abuse.

Regarding the school as a scenario, the most common places where abuses occur can be listed:

- Round trip to school. Both those who walk, as those who are made on the school bus.

- Dinning room.

- Playground.

- The classroom.

- The bathrooms.

- The changing rooms.

- The halls. 
- Sports courts, gym or pool.

- The car parks of the institutes.

- The streets near the school (especially at the time of departure or entry to classes).

Regarding the school as an active agent, it is important to take into account the following aspects:

- School management: the principals mark the guidelines to be followed in their centers in all aspects, and also in those related to bullying. The center's management can choose to train teachers about bullying, form working groups on the school climate or arrange for special attention to be given to students who may suffer aggression, for example. (Charach, Pepler \& Ziegler, 1995)

- Relationship between students and the professional team of the school: it is demonstrated that there are fewer cases of bullying in those centers where there is a close relationship and cooperation between professionals and students. It is also very important that the center's staff does not offer students violent models (Olweus, 1987).

- Anti-bullying policies that are adopted: logically, if the school takes part in a series of antibullying policies, the harassment will tend to diminish.

- Supervision of spaces where abuses usually occur: previously, we have cited those spaces in which aggressions usually occur. The investigations show that the supervision of these spaces by an adult, reduces considerably the rates of harassment. In addition, if the staff monitoring these spaces has received specific training on bullying and conflict resolution, the rates decrease much more (Murphy, Hutchinson \& Bailey, 1983).

- General organization of the center: finally, we must mention the global form in which the school is organized, to the objectives that are set. If the center's global policies opt for coexistence, respect and intercooperation in learning, it will be more difficult for situations of bullying to appear. If, on the other hand, the center follows very competitive principles, or individualism 
prevails, it is easier for aggressive behaviors to appear.

\section{The Teaching Staff}

The studies coincide in underlining the great importance of the role of teachers in cases of bullying. Faced with an aggression, the role of the faculty can be played in different ways, which positively or negatively influence both the victim and the aggressor (Yoon \& Kerber, 2003):

- No intervention. Ignore the facts.

- Allow those involved to solve the problem among themselves, for example by apologizing the aggressor.

- Discuss the problem with the rest of the class.

- Take measures against the aggressor, imposing a punishment.

- Inform the center's management and the parents of those involved.

$85 \%$ of teachers say they intervene in cases of bullying (Yoon \& Kerber, 2003). However, the perceptions of the students are not so optimistic, and reduce that percentage to only $35 \%$. This may be due to something that several researches indicate: teachers usually intervene and pay more attention in cases of physical or verbal harassment, since they are more direct actions, but they do not act so often in cases of social exclusion.

\section{The Family}

Several studies (Smokowski \& Kopasz, 2005; Rodki \& Hodges, 2003) inquire about the role of the families of the students who are victims of the harassment, but also about the families of the aggressors.

As for the families of the victims, they seem to have a tendency towards overprotection of their sons and daughters. On the one hand, overprotection can be a risk factor to be a victim of school bullying; since an overprotected child will have fewer tools to cope with and avoid harassment. On the other hand, victims of bullying also have some family overprotection once the harassment situation is brought to an end, as the parents will support their children by all means so that the abuses do not happen again. Thus, an excess of family protection can be at the same time the cause and consequence of bullying. 
As for the families of the aggressors, the studies seem to indicate that they may not pay due attention to their children. This fact often has nothing to do with lack of care, but with a style of too permissive relationship. For example, when they learn about the abuses their children commit, they consider it "children's things" and even, in the case of their sons, they can see it as something normal. The studies carried out also point out that aggressors often learn at home that violence can be useful in some cases.

\section{Society / Media / Politicians}

The school is not a separate entity from society, but represents and reflects society itself. This affirmation has a great relation with the cases of school bullying since, in the end, the victims of bullying are often marked socially. For example, in a homophobic and hostile to immigration society, it is not surprising that immigrant students and homosexual students are also excluded by their schoolmates.

On the other hand, in addition to tolerance towards difference, society manifests more or less tolerance to cases of bullying. When studying the prevalence by countries, we will find some where bullying is even considered beneficial for the development of minors. This tolerance or social intolerance in the face of bullying is faithfully reflected in the media.

A study of the Spanish press (Márquez \& Jáuregui, 2005) would show us four significant attitudes:

- Political discourse of denial of the conflict. Examples: "the counselor denies that there is violence in the classrooms and speaks of disciplinary conflicts" or in a case of harassment affirming that "it is a case of aggression and an isolated case".

- Reclaiming speech of teachers. More means, more support, more training, creation of specialized bodies ... etc.

- Speech committed by the specialists.

- Absence of students. Taboo and silence on the part of the peer group.

Finally, note the great importance of the involvement of the political class in the fight against bullying. As we will see when studying the situation of some countries, until there is a serious event, the suicide of a victim or the murder of an aggressor, the necessary attention is not devoted 
to bullying.

\section{Conclusions}

The main conclusion of this research is to confirm that bullying is a phenomenon that transcends the individual and does not occur only between two people, a bully and the victim. As we can see, the peer group, the school, the family and society in general also play an important role. This statement involves three new lines of work.

The first of these would be an invitation to construct a definition of bullying according to this complex reality, including in it the other actors that are not only the victim and the bully. Linked to this, we would find a second line, which would be to conduct research on bullying from this complex perspective of multiple roles playing at the same time (from case studies, to surveys or macro analysis). Finally, also to recommend taking into account this diversity of roles when it comes to building policies, plans, programs and projects for the prevention and intervention in cases of bullying.

\section{References}

Avilés, J.M. (2006). Diferencias de atribución causal en el bullying entre sus protagonistas. Revista Electrónica de Investigación Psicoeducativa, 4 (2), 201-220.

Charach, A., Pepler, D. \& Ziegler, S. (1995). Bullying at School: A Canadian perspective. Education Canada, 35, 12-18.

Eisenberg, M. E., Neumark-Sztainer, D. \&Perry, C. L. (2003). Peer Harassment, School Connectedness, and Academic Achievement. Journal of School Health, 73, 311-316. doi:10.1111/j.17461561.2003.tb06588.x

Eslea, M. \&Rees, J. (2001). At what age are children most likely to be bullied at school? Aggresive behavior, 27, 419-429. doi:10.1002/ab.1027

Fleschler, M. Tortolero, S. \& Markham, C. (2006). Bullying and victimization among black and hispanic adolescents. Adolescence, 4l(163), 467-484. 
Fox, J. \& Boulton, M. (2005). The social skills problems of victims of bullying: self, peer and teacher perceptions. British Journal of Educational Psychology, 75(2), 313-328.

doi:10.1348/000709905X25517

Furlong, M.; Morrison, G. \& Greif, J. (2003). Reaching an American

Consensus: reactions to the special Issue on school bullying. School Psychology Review, 32(3), 456-470.

Genevat, R.; Del Rey, R. \& Ortega, R. (2002) Etiquetas verbales en el vocabulario de docentes, padres y madres para nominar el fenómeno bullying. Revista Electrónica Interuniversitaria de Formación del Profesorado, 5(4), 1-2.

Hall, W.J. \& Chapman, M.V. (2018). The Role of School Context in Implementing a Statewide Anti-Bullying Policy and Protecting Students. Educational Policy, 32(4), 507-539.

doi:10.1177/0895904816637689

O'Hanlon, L. H. (2006). Hostile Halls. Current Health, 33(2), 16.

Honwood, J. Waylen, A. Herrick, D. et. al (2005). Common visual defects and peer victimization in children. Investigative Ophthalmology \& Visual Science, 46(4), 1177-1181. doi: 10.1167/iovs.04-0597

DDP (2000). Informe sobre violencia escolar: el maltrato entre iguales en la educación secundaria obligatoria. Madrid: Publicaciones de la Oficina del Defensor del Pueblo

Goldbach, J.T., Sterzing, P.R. \& Stuart, M.J. (2018). Challenging

Conventions of Bullying Thresholds: Exploring Differences between Low and High Levels of Bully-Only, Victim-Only, and Bully-Victim Roles. Journal of Youth and Adolescence, 47(3), 586-600. doi:10.1007/s10964-017-0775-4

Johnson, H. R., Thompson, M. J., Wilkinson, S., Walsh, L., Balding, J., \& Wright, V. (2002). Vulnerability to bullying: Teacher-reported conduct and emotional problems, hyperactivity, peer relationship difficulties, and prosocial behaviour in primary school children. Educational Psychology, 22(5), 553-556.

doi:10.1080/0144341022000023626

Karstadt, L. \& Woods, S. (1999). The school bullying problem. Nursing Standar, 14(2), 32-35. 
Lawrence, G., \& Adams, F. (2006). For Every Bully There is a Victim. American Secondary Education, 35(1), 66-71.

Lodge, J., \& Frydenberg, E. (2005). The Role of Peer Bystanders in School Bullying: Positive Steps toward Promoting Peaceful Schools. Theory

Into Practice, 44(4), 329-336.

Long, C. (2006). Sugar and spice? NEA Today, 30-33.

Longobardi, C., Iotti, N.O., Jungert, T., Settanni, M. (2018). Student-teacher

relationships and bullying: The role of student social status. Journal of Adolescence, 63, 1-10. doi:10.1016/j.adolescence.2017.12.001

Lynch, E. (2004). Lasting damage. Nursing Standar, 18(45), 18-9

Mahady, M.; Craig W. \& Pepler, D. (2000). Emotional regulation and display in classroom victims of bullying: characteristic expressions of afect, coping styles and relevant contextual factors. Social Development, 9, 226-245. doi:10.1111/1467-9507.00121

Márquez, M. \& Jáuregui, I. (2005) La violencia escolar en los textos periodísticos. Revista Iberoamericana de Educación, 38, 105-119.

Retrieved from https://rieoei.org/RIE/article/view/833

Murphy, H.A., Hutchinson, J.M., \& Bailey, J.S. (1983). Behavioral school psychology goes outdoors: The effect of organized games on playground aggression. Journal of Applied Behavior Analysis, 16, 2935. doi:10.1901/jaba.1983.16-29

Nappa, M.R., Palladino, B.E., Menesini, E. \& Baiocco, R. (2018). Teachers' Reaction in Homophobic Bullying Incidents: the Role of Self-efficacy and Homophobic Attitudes. Sexuality Research and Social Policy, 15 (2), 208-218. doi: 10.1007/s13178-017-0306-9

Naylor, P. et al. (2006). Teachers' and pupils' definitions of bullying. British Journal of Educational Psychology, 76(3), 553-576. doi:

10.1348/000709905X52229

Nordhagen, R., Nielsen, A., Stigum, H. \& Köhler, L. (2005). Parental reported bullying among Nordic children: a population-based study. Child: Care, Health and Development, 31, 693-701. doi:10.1111/j.1365-2214.2005.00559.x

Olweus, D. (1987.). School-yard bullying-Grounds for intervention. School Safety, 6, 4-11.

Olweus, D. (1998). Conductas de acoso y amenaza entre escolares. Madrid: Ed. Morata. 
Oñate, A. \& Piñuel, I. (2006). Acoso y violencia escolar en España. Informe Cisneros X.

Patterson, G. (2005). The bully as a victim? Pediatric nursing, 17(10), 2730. doi: 10.7748/paed2005.12.17.10.27.c981

Phoenix, A. Frosh, S. \& Pattman, R. (2003). Producing contradictory masculine subject positions: narratives of threat, homophobia and bullying in 11-14 year old boys. Journal of Social Issues, 59, 179-195. doi:10.1111/1540-4560.t01-1-00011

Richter, L.; Palmary, L. \& De Wet, T. (2000). The transmission of violence in schools: birth to ten children's experiences of bullying. Urban Health \& Development Bulletin, 3, 19-22.

Rigby, K \& Johnson, B. (2005). Student bystanders in Australian Schools. Pastoral Care in Education, 23, 10-16. doi:10.1111/j.02643944.2005.00326.x

Rigby, K \& Johnson, B. (2006). Expressed readiness of Australian Schoolchildren to act as bystandres in support of children who are being bullied. Educational Psychology, 26(3), 425-440. doi: 10.1080/01443410500342047

Rodkin, P. \& Hodges, E. (2003). Bullies and victims in the peer ecology: four questions for psychologists and school professionals. School psychology Review, 32(3), 384-400.

Roland, E. (2002). Bullying, depressive symptoms and suicidial thoughts. Education Research, 44(1), 55-67. doi: 10.1080/00131880110107351.

Roland, E. \& Galloway, D. (2003) Classroom influences on bullying. Educational research, 44(3), 299-312. doi:

$10.1080 / 0013188022000031597$

Root, T. (2005). Student/teacher partnerships can be the key to combat bullying. Education Journal, 92, 7.

Salmivalli, C. (2002). Is there an age decline in victimization by peers at school? Educational Research, 44 (3), 269-277. doi:

10.1080/00131880210135331

Salmivalli, C.; Karhunen J. \& Lagerspetz, K. (1996). How do the victims respond to bullying? Aggressive Behavior, 22, 99-109. doi:10.1002/(SICI)1098-2337 
Smith, P. Singer, M Hoel, H. \& Cooper, C. (2003) Victimization in the school and the workplace: are there any links. British Journal of Psychology, 94, 175-188. doi:10.1348/000712603321661868

Smith, P. (2006). Ciberacoso: naturaleza y extensión de un nuevo tipo de acoso dentro y fuera de la escuela. Ponencia del Congreso de Educación celebrado en Palma de Mallorca en el año 2006.

Smokowski, P. \& Kopasz, K.H. (2005). Bullying in school: an overview of types, effects, family characteristics, and State Legislatures. Children \& Schools, 27(2), 101-110

Stover, D. (2006). Treating Cyberbullying as a school violence issue. Education Digest, 72 (4), 40-42.

Sutton, J. Smith, P. \& Swettenham J. (1999) Bullying and theory of mind: a critique of the social skills deficit view of anti-social behaviour. Social Development, 8, 117-127. doi:10.1111/1467-9507.00083

Tettner, A. (2005). La violencia va a la escuela: manual para la prevención y resolución de conflictos. Caracas: Comala.

Urra, M. (2017). Bullying, acoso escolar. Definición, roles, prevalencia y propuestas de actuación. Paper. Retrieved from: osf.io/preprints/socarxiv/fxsy3. doi: 10.17605/OSF.IO/FXSY3

Yoon, J. \& Kerber, K. (2003). Bullying. Elementary teachers' ${ }^{\prime}$ attitudes and intervention strategies. Reseach in Education, 69, 27-35.

Zhu, Y., Chan, K.L. \& Chen, J. (2018). Bullying Victimization Among Chinese Middle School Students: The Role of Family Violence. Journal of Interpersonal Violence, 33(12), 1958-1977. doi:10.1177/0886260515621082

Miguel Urra Canales is Professor at University of Santo Tomás, Colombia

Catalina Acosta Oidor is Professor at University of Santo Tomás, Colombia

Verónica Salazar Baena is Professor at University of Santo Tomás, Colombia

Edwin Jaime Ruiz is Professor at University of Santo Tomás, Colombia Contact Address: dec.sociologia@usantotomas.edu.co 